Economics Development Analysis Journal

\title{
The Influence of Cigarette Consumption Towards Poverty in Central Java Province
}

\author{
Agnes Marisca Dian Sari ${ }^{\bowtie}$
}

Bank Central Asia

\section{Article Info}

Article History :

Received April 2016

Accepted June 2016

Published August 2016

Keywords:

Poverty; Cigarette

Consumption; Cigarette Tax

\begin{abstract}
The aims of this research were to find out the effects of poverty on cigarette consumption in Central Java in 2013 and to recognize the effects of tax cigarette on cigarette consumption in Central Java in 2013. The type of the data used was secondary data. The analysis method used was the regression of Ordinary Least Square (OLS) with the cross section data of 2013 in 35 Districts of Central Java Province.The research results show that when the Poverty Line increases, it increases cigarette consumption. The variable on Poverty Line has effect on cigarette consumption in Central Java in 2013. The variable of cigarette tax has positive insignificant value. The variables of poverty and cigarette tax are able to explain the level of cigarette consumption of $0.1263 \%$, and the remaining variables are explained by the other variables. F- statistic is 2,31, F-table is 1,37, and t-table is 2.034. Based on the research results, it can be concluded that there is a significant association between cigarette consumption and poverty in Central Java in 2013. When cigarette consumption rose, it increased the poverty in Central Java in 2013. The association between cigarette consumption and cigarette tax in Central Java in 2013 was not significant but had positive value. It means that the tax policy in Central Java is not able to reduce cigarette consumption in Central Java in 2013. Although there has been a cigarette tax, the cigarette consumption continues to increase.
\end{abstract}

E-mail:edaj@mail.unnes.ac.id 


\section{INTRODUCTION}

According to The Tobacco Atlas 3rd edition (2009), ASEAN is an area with 10 percent world smokers and causing global deaths due to tobacco. Percentage of smokers in the population of the largest ASEAN countries in Indonesia (46.16\%), Philippines (16.62\%), Vietnam (14.11\%), Myanmar (8.73\%), Thailand (7.74\%), Malaysia (2.90\%), Cambodia (2.07\%), Laos $(1.23 \%)$, Singapore $(0.39 \%)$, and Brunei $(0.04 \%)$. According to the World Health Organization (WHO), the prevalence of adults who smoke in Indonesia is quite high at 29 percent. Based on the National Socioeconomic Survey (Susenas) in 2004 showed that the prevalence of male smokers from the age of 15 is 63 percent. The results of the Central Java Provincial Health Research (Riskesdas 2007) stated that teenagers (15-19 years old) who smoked daily were 24.3 percent, with average cigarretes consumption is 8.9 cigarettes per days.

Cigarette consumption is a concern for developing countries such as Indonesia and as contributors to poverty. Most of the Indonesian population are active smokers which means contribute towards poverty line. According to the Central Statistics Bureau (BPS), poverty in Indonesia can be reduced if cigarette consumption in Indonesia also reduced. society in the vicious circle, especially in the poor. Consumption of cigarettes poses a danger to health level because the ingredients in cigarettes has substances that are harmful to health.

The Excise Law stipulates that excise tariffs aims to reduce consumption of tobacco products and control the distribution because these products are harmful. There are about two million deaths per year because of tobacco for all of the combined developed countries (Peto, Lopez, Boreham, Thun, \& Heath, 1994) in (Liu et al., 2006). Increasing the tobacco excise tax rate become the most effective way to increase health level and decrease the economic losses due to tobacco consumption. However, cigarette consumption in Indonesia continues to increase. Peretti-Watel et al., (2012) prove that to reduce the number of smokers, the French government tend to raise the price of cigarettes. However, 24 percent of smokers do not change the habit at all, 31 percent only reduce the cost of smoking (not reducing consumption or trying to quit) and 45 percent trying to reduce their consumption. The existence of a tobacco tax policy is expected on the one hand to increase local revenue and on the other hand to control cigarette consumption. When cigarettes are taxed, it will increase the price of cigarettes and people are expected to reduce cigarette consumption.

Cigarette tax revenues in Central Java are considered high because there are so many large cigarette manufacturers such as Djarum 76 and many more. Central Java includes 3 provinces that have a large revenue in tax cigarettes which can be seen in the following table:

Table 1. Three province who obtained a much revenue

\begin{tabular}{lll}
\hline Provinsi & \multicolumn{1}{c}{$\mathbf{2 0 1 3}$} & \multicolumn{1}{c}{$\mathbf{2 0 1 4}$} \\
\hline West Java & 1.124 .515 .106 .538 & 1.327 .293 .273 .728 \\
East Java & 945.485 .014 .895 & 1.156 .195 .865 .059 \\
Central & 807.216 .378 .989 & 998.996 .836 .060 \\
Java & & \\
\hline
\end{tabular}

Source: General Guidelines on the Use of Cigarette Tax Funds for the Health Sector.

Of the 33 Provinces in Indonesia, Central Java placed the 3rd position with the highest tax revenue. In 2013, the tax receipts amounted to Rp $807,216,378,989$ with contribution of 13.13 percent and in $2014 \mathrm{Rp} 998.996 .836 .060$ with contribution of 13.63 percent.

Taxes and other government levies on tobacco products consist of Value Added Tax, Excise and Cigarette Taxes. Value Added Tax and excise tax is the central government tax while the cigarette tax is a local tax which is collected along with the imposition of excise duty. Cigarette Tax is a levy on cigarette taxes collected by the Government. In accordance with Law Number 28 Year 2009 on Regional Tax and Regional Retribution, regional government in particular province is authorized to collect cigarette tax of 10 percent from national cigarette excise tariff. The object of cigarette tax is cigarette consumption, consisting of cigars, and leaf 
cigarettes. While the subject is consumer of cigarette, with taxpayer of cigarette manufacturer / producer and importer of cigarettes that have license of customs product of goods of taxable goods (NPPBKC).

Cigarette consumption occupies second position after rice in the list of food commodities. The government implements excise and taxes in an effort that the poor will reduce consumption of cigarettes and divert their consumption to other foodstuffs. Poverty level in Central Java is quite high compared with other provinces. According to BPS in September 2013 the number of poor people reached $4.704,87$ million. During the period from March to September 2013, the poor in urban areas decreased by approximately 40.48 thousand people (from 1,911.21 thousand in March 2013 to $1,870.73$ thousand in September 2013), while in rural areas increased by 12.40 thousand people (from 2,821,74 thousand in March 2013 to 2,834.14 thousand people in September 2013).

The percentage of poor people in urban areas in March 2013 of 12.87 percent decreased to 12.53 percent in September 2013. But the percentage of poor people in rural areas increased from 15.99 percent in March 2013 to 16.05 percent in September 2013. The higher consumption of cigarettes in Central Java causes the poverty rate in Central Java to be high. The problem in this research is what is the relationship between poverty and cigarettes consumption in Central Java and the relationship between cigarette tax and cigarette consumption in Central Java. This research aims to know the effect of poverty with cigarette consumption in Central Java and to know the effect of tax cigarettes with cigarette consumption in Central Java.

Salvatore in (Anwar, 2007) argues that individuals ask for a particular commodity because of the satisfaction received from consuming a unit good. The more units the individual consumes per unit of time, the greater the total utility to be received. According to Anwar, (2007) consumption is a human activity using goods or services to meet the needs. The quality and quantity of goods used by consumers shows the level of consumer prosperity. The purpose of self-consumption is to achieve maximum satisfaction from the combination of goods or services.

Poverty is an illustration of the condition of absence of ownership and low income, or in more detail describes a condition of nonfulfillment of basic human needs, namely food, boards, and clothing. Individuals living in poverty remain an important issue (Bruton et al., 2013). Some definitions describe the condition of the absence. One of them is the definition of poverty used by the Central Bureau of Statistics (BPS), which describes poverty as the inability of individuals to meet basic minimum needs for decent living.

Measuring poverty, BPS uses the concept of basic needs approach. With this approach, poverty is seen as an inability from the economic side to meet the basic needs of food and not food as measured by the expenditure side. So Poor People are residents who have average monthly per capita expenditure below the poverty line.

The food poverty line (GKM) is the value of the expenditure of food and beverages which is equalized with 2100 kilocalories per capita per day. The basic food commodity package is represented by 52 types of commodities (whole grains, tubers, fish, eggs and milk, vegetables, beans, fruits, oils and fats, etc.). The non-food poverty line is the minimum needs for housing, clothing, education and health. Non food basic commodity is represented by 51 kinds of commodity in urban and 47 kinds of commodity in rural area.

Cigarette tax is a levy on cigarette taxes by the Government. In accordance with Law Number 28 Year 2009 regarding Regional Tax and Regional Retribution, Regional Government especially Province is given the authority to collect cigarette tax of 10 percent from national cigarette excise tariff. The object of cigarette tax is cigarette consumption, consisting of cigarettes, cigars, and leaf cigarettes. While the subject is consumer of cigarette, with taxpayer of cigarette manufacturer / producer and importer of cigarettes that have license of customs product of goods of taxable goods (NPPBKC). 
Cigarette taxes are levied by the government together with the collection of cigarette excise taxes and paid into provincial public cash accounts proportionately, based on population. The basis for the imposition of tobacco tax is the cigarette excise duty, with the tariff of 10 percent of cigarette excise tax. Utilization of cigarette tax at least 50 percent to fund health services and law enforcement by authorized officers.

\section{RESEARCH METHOD}

The type of data used in this study is secondary data. Data taken from existing sources that have been processed by a third party, within a certain time (at a point of time) that can describe the situation at that time. The data obtained from BPS, publication files from the Ministry of Health and RISKESDAS Central Java in 2013. Data collection methods used in this study are: Literature study from associated cigarette consumption and poverty, as well as other sources such as documents in BPS, Riskesdas, general manual on the use of taxes on health cigarettes, which are linked to this research. Other information comes from other literary studies in the form of scientific journals and textbooks.

There are three variables that is cigarette consumption (Y), poverty (X1), and cigarette tax (X2). The analytical method used is Ordinary Least Square (OLS) regression with cross section data of 2013 in Central Java Province with 35 districts / cities. With R-Square Test, F-Statistic Test, T-Statistic Test, Normality Test, Multicolinearity Test, and Heteroscedasticity Test.

\section{RESULTS AND DISCUSSION}

Multiple regression analysis used to analyze the influence of independent variables to the dependent variable. Regression analysis aims to calculate the influence of the poverty line and taxes on cigarette consumption in Central Java. The results of this regression using a tool that is computer program Eviews 8.0. The results of multiple regression in the can is as follows:

Table 2. Multiple regression output

\begin{tabular}{lllll}
\hline Variable & Coefficient & Std. Error & t-Statistic & Prob. \\
\hline $\mathrm{C}$ & 2682,959 & 607,4643 & 4,416640 & 0,0001 \\
$\mathrm{X}_{1}$ & 0,003597 & 0,001692 & 2,126210 & 0,0413 \\
$\mathrm{X}_{2}$ & 0,00000000117 & 0,00000000102 & 0,114600 & 0,9095 \\
\hline
\end{tabular}

Source: Data processed

The multiple regression equation between poverty line (X1), tax (X2), and cigarette consumption (Y) in Central Java Province in 2013 is

$Y=2682,59+0,003597 X_{1}+0,00000000117 X_{2}$ $+\mathrm{e}$

Whereas:

Y cigarretes consumption

$\mathrm{X}_{1} \quad$ Poverty line

$\mathrm{X}_{2} \quad$ Cigarretes tax

e Error

From the results of the regression model it can be made a statistical interpretation of changes in the dependent variable caused by changes in independent variables. (1) The value of the constant is 2682.59. It means that without the variables of poverty line and cigarette tax, the cigarettes consumption of Central Java people is 2683 stems; (2) The coefficient value X1 (Poverty line) is 0.003597 . It means that if the increase of poverty line 1 rupiah will be followed by the increase of cigarette consumption by 0.003 cigarettes. This shows that significant hypothesis of positive influence and significant variable of poverty line to cigarette consumption; (3) The coefficient value $\mathrm{X} 2$ (cigarette tax) is 0,00000000117 . It means that if the increase of cigarette tax 1 rupiah will be followed by the 
increase of cigarette consumption by 0.00 cigarettes.

Based on the output, the value of coefficient determination (R2) is 0.126323 which means that the independent variables of poverty line and cigarette taxes together have a significant effect on tobacco consumption of 12.63 percent while the remaining 87.37 percent is explained by other varibels that are not included in the estimation model.

The regression analysis of poverty line (X1), cigarette tax (X2), on cigarette consumption
(Y) in Central Java Province used $95 \%(\alpha=0.05)$ degree of confidence resulting F-table of 1.37. While the F-statistics of 2.31 and probability value $F$-statistic 0.115243 . So it can be concluded that the independent variables together affect the dependent variable. Individually, cigarette tax (X2) has a significant and positive effect on cigarette consumption (Y) in Central Java. The poverty line (X1) has an insignificant and positive effect on cigarette consumption (Y) in Central Java with $\alpha=5 \%$ or $95 \%$ confidence level.

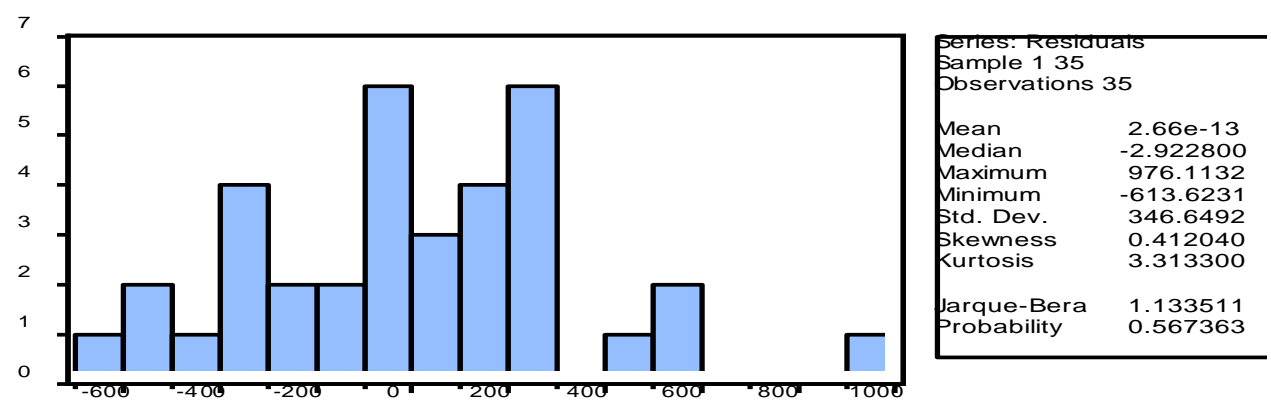

Figure 1. Normality test

Source: data processed

The normality test shows that residual have probability value 0,56 and level significance more than 0,05 . The value of Jarque-Bera in this data is 1.133469 with X2 of 45.77. Jarque-Bera is smaller than X2. Based on the above table, it can be concluded that residuals have data derived from normal population.

Table 3. Collinearity test

\begin{tabular}{lll}
\hline & Poverty_line & Tax \\
Poverty line & 1 & -0.2038 \\
\hline Pajak & -0.2038 & 1 \\
\hline
\end{tabular}

Source: Data processed

The table above shows the correlation between the poverty line with the cigarette tax of -0.2038 , with correlation coefficient ( $r$ ) among independent variables on the model used in the research $<0.80$, it can be stated that there is no collinearity in the research model.

Table 4. Heteroskedasticity Test White

\begin{tabular}{llll}
\hline F-statistic & 1.334499 & Prob.F(2,32) & 0.2775 \\
\hline Obs*R-Squared Scaled $^{\star}$ & 2.694480 & Prob.Chi-Square(2) & 0.2600 \\
ExplainedSS & 2.605179 & Prob.Chi-Square(2) & 0.2718 \\
\hline
\end{tabular}

Source: Data processed

The method used to detect the presence of shows that the model does not contain heteroskedastisitas is White testing. Table 4 heteroscedasticity. The probability value of Chi 
Squares of 0.2600 is greater than the value of $\alpha$ of 0.05 .

The poverty line and cigarette consumption relation are positive, which means that when cigarette consumption increases, it will increase cigarette consumption and vice versa. When cigarette consumption decreases, poverty tends to decrease. Poverty can be reduced if cigarette consumption is controlled. Reducing cigarette consumption to meet other nutritional needs or non-food needs such as education and health. Cigarettes have absolutely no caloric value so they can not contribute to poverty reduction from the poverty line. As cigarette consumption increases, it will contribute to improving the poor to get away from the poverty line.

When the poverty line rises it will increase cigarette consumption. The poverty line affects tobacco consumption in Central Java. This finding is in line with WHO that cigarette consumption in the poor is higher than cigarette consumption in middle income communities. Furthermore, according to BPS, poverty declines if cigarette consumption decreases.

According to Muhammad and Tri cigarette consumption is not beneficial to life and will even damage health. The expenditure of cigarettes on poor households is very high. So that makes the inspiration of the government not to provide assistance in the form of raskin, Jamkesmas or other assistance to poor households. The number and percentage of expenditure used for smoking in RTM is higher than RTSM. It can be said that in poor households the higher income will increase the consumption for smoking. Spending on cigarette exceeds spending on education or health. The percentage of poor households consuming cigarettes in 2008 reached 46.33 percent. Which means almost half of smokers in Indonesia are classified by below the poverty line.

Cigarette tax variables do not affect cigarette consumption in Central Java. This means that the government's intention with the tax to reduce cigarette consumption has not been in good response by active smokers. According to the data, cigarette tax does not affect cigarette consumption. Active smokers continue to buy cigarettes even though cigarette prices rise due to the addition of cigarette taxes. In addition, the price of cigarettes is still accessible by active smokers even though they must ignore other nutritional needs to meet the cigarettes.

\section{CONCLUSION}

Based on the results of this study there are significant effect of poverty line on tobacco consumption in Central Java. When the consumption of cigarettes in Central Java increase, it would arise the poverty line. Therefore, There is no effect of cigarette tax on cigarette consumption in Central Java. This means that tax policy is not able to reduce cigarette consumption in Central Java. Although there is no cigarette tax, cigarette consumption continues to increase.

\section{REFERENCES}

Ahsan, A. 2006. "The Effect of Socio-Economic Factors on Individual Smoking Behavior: Analysis of Susenas 2004 Data". Thesis, Jakarta: University of Indonesia.

2012. Poverty: table of the number of poor people. BPS, Jakarta 2014. Central Java In Figures 2013. Central Java. BPS, Central Java Province

Bruton, G.D., Ketchen Jr., D.J. \& Ireland, R.D., 2013. Entrepreneurship as a solution to poverty. Journal of Business Venturing.

Central Bureau of Statistics. 2013. The Concept of Poverty. BPS, Central Java Province.

Buku Panduan Umum Penggunaan Dana Pajak Rokok Untuk Bidang Kesehatan

Firdaus, Muhammad and Tri Suryaningsih. 2009. Poverty and High Consumption of Cigarettes: Factors Cause the Difficulties of Green Economy Implementation in Java. Bogor. Faculty of Economics Management Bogor Agricultural University.

Ministry of Health. Infodatin. Resource and Information Center Ministry of Health RI. Ministry of Health. Republic of Indonesia.

Liu, et al., 2006. Cigarette smoking and poverty in China. Social Science \& Medicine, pp. 2784-2790.

Mackay, J. \& Erikson, M. 2002. The Tobacco Atlas. Bringhton, UK, World Health Organization (WHO). 
Maisaroh, S., \& Sukhemi, S. (2015). Community Empower Through Entrepreneurship Cultural Development To Reduce Unemployment And Poverty. Jejak: Journal of Economics and Policy, 4 (1).

Minister of Health. 2012. Facts of Tobacco. Tobacco Control Support Center. Association of Indonesian Public Health Experts.

Peretti-Watel,, L'haridon, \& Seror,, 2012. Responses to increase cigarette prices in France: How did persistent smokers react?. Health Policy, pp.169176.

Puspita, D. (2015). Poverty determinant analysis in central java province. Jejak: Journal of Economics and Policy, 8 (1).

Rahman, Y. (2015). Implementation of urban poverty program implementation (P2KP) in tonjong district brebes district in 2007. Jejak : Journal of Economics and Policy, 3 (1).
Riskesdas. 2013. Report of Central Java Province. Agency for Health Research and Development. Ministry of Health, Republic of Indonesia.

Surjono, Nasurddin Djokok and Piping Setyo Handayani. 2013. The impact of cigarette income and prices on the level of cigarette consumption in poor households in Indonesia. Financial Education and Training Agency of the Ministry of Finance of the Republic of Indonesia.

Law Number 28 Year 2009 regarding Regional Tax and Regional Retribution. Jakarta.

Of Law of the Republic of Indonesia Number 28 of 2007 concerning the Third Amendment to Law Number 6 of 1983 concerning the General Provisions and Procedures for Taxation in Jakarta.

Riskesdas. 2007. Report of Central Java Province. Agency for Health Research and Development. Ministry of Health, Republic of Indonesia. 